\title{
Technical note: Application of geophysical tools for tree root studies in forest ecosystems in complex soils
}

\author{
Ulises Rodríguez-Robles ${ }^{1, \text { a }}$, Tulio Arredondo ${ }^{1}$, Elisabeth Huber-Sannwald ${ }^{1}$, José Alfredo Ramos-Leal ${ }^{2}$, and \\ Enrico A. Yépez ${ }^{3}$ \\ ${ }^{1}$ División de Ciencias Ambientales, Instituto Potosino de Investigación Científica y Tecnológica, \\ Camino a la Presa de San José \# 2055, Lomas 4ta Sección, C.P. 78216 San Luis Potosí, S.L.P., Mexico \\ ${ }^{2}$ División de Geociencias Aplicadas, Instituto Potosino de Investigación Científica y Tecnológica, \\ Camino a la Presa de San José \# 2055, Lomas 4ta Sección, C.P. 78216 San Luis Potosí, S.L.P., Mexico \\ ${ }^{3}$ Departamento de Ciencias del Agua y Medio Ambiente, Instituto Tecnológico de Sonora, \\ 5 de Febrero 818 Sur, Col. Centro, C.P. 8500 Ciudad Obregón, Mexico \\ a current address: Cátedras CONACyT, El Colegio de la Frontera Sur, Villahermosa, Mexico
}

Correspondence to: Tulio Arredondo (tulio@ipicyt.edu.mx)

Received: 14 March 2017 - Discussion started: 29 March 2017

Revised: 14 October 2017 - Accepted: 23 October 2017 - Published: 30 November 2017

\begin{abstract}
While semiarid forests frequently colonize rocky substrates, knowledge is scarce on how roots garner resources in these extreme habitats. The Sierra San Miguelito Volcanic Complex in central Mexico exhibits shallow soils and impermeable rhyolitic-rock outcrops, which impede water movement and root placement beyond the soil matrix. However, rock fractures, exfoliated rocks and soil pockets potentially permit downward water percolation and root growth. With ground-penetrating radar (GPR) and electrical resistivity tomography (ERT), two geophysical methods advocated by Jayawickreme et al. (2014) to advance root ecology, we advanced in the method development studying root and water distribution in shallow rocky soils and rock fractures in a semiarid forest. We calibrated geophysical images with in situ root measurements, and then extrapolated root distribution over larger areas. Using GPR shielded antennas, we identified both fine and coarse pine and oak roots from 0.6 to $7.5 \mathrm{~cm}$ diameter at different depths into either soil or rock fractures. We also detected, trees anchoring their trunks using coarse roots underneath rock outcroppings. With ERT, we tracked monthly changes in humidity at the soil-bedrock interface, which clearly explained spatial root distribution of both tree species. Geophysical methods have enormous potential in elucidating root ecology. More interdisciplinary research could advance our understanding in belowground eco-
\end{abstract}

logical niche functions and their role in forest ecohydrology and productivity.

\section{Introduction}

Strategies of plant water use and mechanisms of water transport on the soil-plant-atmosphere continuum are critical to understand ecosystem functioning in arid and semiarid regions, where plant productivity is primarily limited by water availability (Prieto et al., 2012; Burgess and Bleby, 2006; Li et al., 2007). Roots' major functions are absorbing water and mineral nutrients, as well as supporting stems and anchoring plants to the ground (Prieto et al., 2012). Growing roots change soil structure, displace pore water and gas and increase porosity (Jackson et al., 1996). Plant water balance and physiological processes depend on the control of root water uptake (Anderegg and HilleRisLambers, 2016). Placement of roots at different soil depths favor both spatial and temporal resource partitioning and effective resource exploitation of whole soil profiles, thereby enhancing biomass production (Fernandez et al., 2000; Brooks et al., 2002; Hultine et al., 2003; Renee et al., 2010). Many ecosystems with shallow soils $(<1 \mathrm{~m})$ are located in water-limited climatic regions with highly variable, seasonal precipitation, where a small water storage potential in the substrate is paramount 
to maintain perennial vegetation cover (Rose et al., 2003; Schwinning, 2010; Rodriguez-Robles et al., 2015). So far, there exist a fair number of studies on hydrological aspects of plants from semiarid regions, in particular from sites where vertical root development is not restricted by hardened soil layers such as in karstic regions (Schwinning and Ehleringer, 2001; Poulos et al., 2007; Lebourgeois et al., 1998; EstradaMedina et al., 2013). Few studies, however, have examined semiarid forest ecosystems with shallow soils forming over bedrock, cemented horizons, or strongly developed argillic horizons that impede downward water movement and root growth (Andrews et al., 2005; Katra et al., 2008; RodriguezRobles et al., 2015).

In semiarid climates, poorly developed shallow soils over water-impermeable substrates rarely exhibit sufficient water storage capacity to maintain forest ecosystems. Empirical evidence suggests that trees and shrubs growing on this type of substrate are able to access water from weathered bedrock once water supply from the top soil becomes exhausted (Schwinning, 2008; Querejeta et al., 2007). Still, the geological context of shallow soils in plant-water relations is controversial both in terms of the physical source of water and the adaptive mechanisms to thrive under these limiting water conditions. This has been the focus of recent ecohydrological studies (Tokumoto et al., 2014; Schwinning, 2013; Rodriguez-Robles et al., 2015; Estrada-Medina et al., 2013). Because of methodological difficulties, the impracticality of bedrock excavation and a general lack of specific research tools to study root distribution in situ, little is known about species-specific rooting patterns and growth strategies of forest ecosystems colonizing shallow soils over bedrock. Complementary methods are needed to simultaneously study vertical root distribution and seasonal soil humidity patterns to elucidate potentially diverse species-specific adaptations to complex geoecohydrological conditions.

With surface geophysical methods, such as electrical resistivity tomography (ERT), it is possible to monitor water content at soil-bedrock depths between 2.5 and $17 \mathrm{~m}$ and at frequent time intervals (Beff et al., 2013). ERT is a nondestructive, geoelectrical method to examine soil properties (Martinez-Pagan et al., 2013); it allows the generation of two- and/or three-dimensional images and maps depicting both the spatial and temporal variation in soil electrical conductivity, corresponding to variations in soil water content (Cosentini et al., 2012), and singularities like cracks and fractures (Travelletti et al., 2012). The resistivity of rocks and soil may vary depending on their water content, water salinity and mode of pore distribution, with a wide range of values $\left(1-10^{9} \Omega \mathrm{m}^{-1}\right)$; lower values indicate higher water content and vice versa (Orellana and Silva, 1982). ERT has traditionally been used in geological prospecting (Chrétien et al., 2014; Sudha et al., 2009; Wang et al., 1991), but it is now also frequently applied in hydrological, agricultural and environmental studies (Srayeddin and Doussan, 2009; Jackson et al., 2000).
Ground-penetrating radar (GPR) is an effective and rapid tool for geophysical surveys because it is non-destructive and delivers real-time information (Parsekian et al., 2015). The GPR permits the use of a variety of antennas with different (high- and low-resolution) frequencies for the examination of different substrates and to be used by multiple disciplines. The ground electrical conductivity, the transmitted center frequency and the radiated power all may limit the effective depth range of GPR prospection. Increases in electrical conductivity in the ground may attenuate the introduced electromagnetic wave, and thus its penetration depth decreases. However, higher GPR frequencies may provide improved resolution. Hence, operating frequency is always a trade-off between resolution and ground penetration (Aditama et al., 2017). The application of GPR ranges from characterizing subsurface stratigraphy (Adepelumi and Fayemi, 2012) and spatial extent of weathered blocks and fracture-cracked systems (Ogretmen and Seren, 2014) to measurements of soil water content (da Silva et al., 2004) and the determination of belowground tree roots of different diameter (with minimum diameter of $5 \mathrm{~mm}$ ) in forest and urban settings (Tanikawa et al., 2013; Ow and Sim, 2012; Hruska et al., 1999). A combined application of GPR with ERT explored the distinction and distribution of roots with different diameters over a broad range of soil conditions in southeastern United States (Butnor et al., 2001). According to their study, soils with high electrical resistivity are the most amenable for root detection with GPR. More recent studies (Zhu et al., 2014; Borden et al., 2014) have tried to track the direction (vertical or horizontal) of root growth and to evaluate the efficiency of GPR in mapping coarse root systems and estimating root biomass under field conditions. However, various factors affect detection of roots using GPR, such as root position, wood density and the conditions surrounding roots. These conditions include, for instance, physical properties, altered or removed material, the volumetric water content, temperature, dissolved solids or salinity, the existence of regolith material, and applied GPR wave frequency. These conditions may interfere with signal transmission and thus resulting in low-quality and difficult-to-interpret profiles (Table 1). For example, root zones in wet conductive soils, high-frequency waves are strongly attenuated limiting the resolution to detect roots and depth penetration (Butnor et al., 2012).

To explore the potential of these geophysical methods in ecology, we examined ecohydrological processes at the soilbedrock-plant root interface in a mixed forest ecosystem in the mountainous region of Sierra San Miguelito (SSM) situated at the transition of the arid desert scrub biome in the north and the semiarid grassland biome in the south of the Mexican Central Plateau. Since the presence and success of pine-oak forests in this macroclimatic semiarid region cannot be explained by mere climate conditions, we used geophysical methods to elucidate the geological and edaphic conditions as well as potential root adaptations to help explain the ecohydrological functioning of this azonal forest. 
Table 1. A cross-study comparison of the detection capacity (minimum and maximum) of tree root diameter and depth in different soil types using GPR systems with various radar frequencies. Rows in bold refer to GPR conditions used in this study.

\begin{tabular}{|c|c|c|c|c|c|c|c|c|}
\hline \multirow{2}{*}{$\begin{array}{l}\text { Radar } \\
\text { frequency } \\
(\mathrm{MHz})\end{array}$} & \multirow[t]{2}{*}{ Tree species } & \multirow[t]{2}{*}{ Soil type } & \multirow[t]{2}{*}{ Site condition } & \multicolumn{2}{|c|}{$\begin{array}{l}\text { Detected root } \\
\text { diameter }(\mathrm{cm})\end{array}$} & \multicolumn{2}{|c|}{$\begin{array}{l}\text { Detected root } \\
\text { depth }(\mathrm{cm})\end{array}$} & \multirow[t]{2}{*}{ Reference } \\
\hline & & & & $\min$ & $\max$ & $\min$ & $\max$ & \\
\hline 400 & Pinus taeda & Georgeville soil & Plantation & 3.7 & 10 & - & 130 & Butnor et al. (2001) \\
\hline 400 & Melaleuca quinquenervia & Flat sandy soil & Controlled, root segments & 3 & 13 & - & 50 & Cheng et al. (2014) \\
\hline 450 & Quercus petraea & Loamy deluvial soil & Plantation & 3 & 5 & - & 200 & Hruska et al. (1999) \\
\hline 500 & Larix kaempferi & Forest soil & Plantation & - & 10 & 10 & 30 & Zhu et al. (2014) \\
\hline 500 & $\begin{array}{l}\text { Quercus potosina, } \\
\text { Pinus cembroides }\end{array}$ & Shallow, rocky soils & Semiarid tropical forest & 2.5 & 7.5 & 3 & 40 & This study \\
\hline 500 & $\begin{array}{l}\text { Ulmus pumila, } \\
\text { Artemisia ordosica }\end{array}$ & Dry sandy & Controlled, fixed sand dunes & - & 3.5 & 10 & 80 & Cui et al. (2011) \\
\hline 800 & Eucalyptus sp. & River sand & Plantation & - & 5 & - & 50 & Barton and Montagu (2004) \\
\hline 800 & $\begin{array}{l}\text { Quercus potosina, } \\
\text { Pinus cembroides }\end{array}$ & Shallow, rocky soils & Semiarid tropical forest & 0.6 & 4 & 1 & 40 & This study \\
\hline 900 & Prunus persica & Faceville fine sandy loam & Controlled, peach orchard & 2.5 & 8.2 & 11 & 114 & Cox et al. (2005) \\
\hline 900 & Different tree species & Red-yellow and marshy soils & Subtropical evergreen forest & 1 & 3 & 1 & 60 & Yan et al. (2013) \\
\hline 1000 & Eucalyptus sp. & River sand & Plantation & 1 & 10 & - & 50 & Barton and Montagu (2004) \\
\hline 1000 & $\begin{array}{l}\text { Quercus douglasii, } \\
\text { Pinus sabiniana }\end{array}$ & Auburn-Exchequer soil & Semiarid savanna & 1.3 & 10 & 8 & 30 & Raz-Yaseef et al. (2013) \\
\hline 1500 & Populus deltoides & Lakeland soil & Plantation & 0.6 & 1.7 & 11 & 27 & Butnor et al. (2001) \\
\hline 2000 & $\begin{array}{l}\text { Ulmus pumila, } \\
\text { Artemisia ordosica }\end{array}$ & Dry sandy & Controlled, fixed sand dunes & 0.5 & 3.5 & - & 30 & Cui et al. (2011) \\
\hline
\end{tabular}

The SSM is a volcanic complex of impermeable rhyolitic rocks, whose surface layers have been highly weathered by exfoliation processes (peeling off in sheets). The forest ecosystems are characterized by shallow, poorly developed soils with high litter and organic matter content $(<25 \mathrm{~cm}$ deep) (Perez et al., 2009). Recent studies suggested that native tree species may be able to extract water directly from subsurface bedrock (Schwinning, 2013; Proust et al., 2011; Tokumoto et al., 2014); however, most of these studies have focused on water-permeable rock types (e.g., limestones). Rodriguez-Robles et al. (2015) suggested that specialized root systems of trees colonizing the shallow rocky soils of SSM explore large regolith rocky areas and thereby increase the likelihood of finding stored water in cracks. However, it is unclear if the water supply encountered in cracks fulfills the water demand of two coexisting tree species, especially during frequently recurring extended seasonal droughts in this region. Also, little is known about the distribution of fine and coarse tree roots growing below shallow soils into weathered bedrock, mainly because of difficulties in excavating bedrock. Overall Quercus species exhibit dimorphic roots, while Pinus species display preferentially superficial roots spreading horizontally (Kutschera and Lichtenegger, 2002).

This study responds to a cross-disciplinary call for the application and wide use of technology from other fields by developing geophysical methods to advance in situ research in root ecology (Jayawickreme et al., 2014). Our study adopted a novel approach to tackle several questions simultaneously and by drawing upon diverse disciplines such as ecosystem ecology, ecohydrology, geophysics and biogeosciences. Here, we present details on the application of surface geophysical imaging tools for root research studies in mixed forests in an edaphically, geologically and climatically extreme and complex environment. We emphasize the application of these tools primarily for exploration and thus as an alternative and/or complement to traditional ecological methods to gather information on ecologically relevant subsurface variables across time and space. We expected weathered rhyolite bedrock in Sierra San Miguelito Volcanic Complex (SSMVC) to conserve humid microsites and that the root distribution of pine-oak forest stands mirrors spatial and temporal heterogeneity of water availability. In particular, we aimed at (1) characterizing the presence and depth of weathered bedrock and demonstrating that exfoliation sites function as potential water sources; (2) with the use of GPR, detecting roots of different diameter size classes growing at various depths in volcanic fractured rock; (3) with the use of ERT, assessing the relationship between soil electrical resistivity and soil water potential in order to determine if resistivity tomography can detect the spatial and temporal variability of soil moisture beneath vegetation patches; and (4) with ERT tomograms and GPR radargrams, describing the functionality of weathered bedrock in forest ecosystems colonizing shallow rocky soils.

\section{Materials and methods}

\subsection{Site description}

The site is situated in SSM, in a semiarid pine-oak forest ecosystem in the southern region of the SSMVC (Fig. S1 in the Supplement). The SSMVC represents the remnants of one of the most voluminous rhyolitic volcanic events on Earth (McDowell and Keizer, 1977), formed by massive 
lava spills of rhyolitic composition (Portezuelo Latite and San Miguelito Rhyolite). Currently, this volcanic complex is affected by small-scale local fracturing through pedogenesis and hydrological processes and thereby is directly influencing pine-oak forest establishment (Fig. 1a-b). Soils are poorly developed and overall extremely shallow $(<25 \mathrm{~cm})$ and rocky; hence, to get support, tree roots commonly anchor in weathered bedrock or beneath rock outcrops (Fig. 1cd). Lithological profiles show a high density of vertical roots in rock fractures and soil pockets (Fig. 1e-f). According to the World Reference Base for Soil Resources (WRB) classification system, the soil at this site corresponds to LithicParalithic Leptosols (LPlip) (FAO, 2006). Organic matter content is very high (60\%) in these soils (Perez et al., 2009). The climate is semiarid; for the last 65 years mean annual precipitation (MAP) has averaged $408 \mathrm{~mm}$ (weather station "La Purisima"; $22^{\circ} 5^{\prime} 22.4^{\prime \prime} \mathrm{N}, 101^{\circ} 12^{\prime} 28.9^{\prime \prime} \mathrm{W}$ ), where in $64 \%$ of the years MAP has been below average and only in $12 \%$ of the years has it been above $500 \mathrm{~mm}$ (Fig. S2). In general, summer precipitation falls between July and October and accounts for $90 \%$ of MAP; the rest falls between December and February.

\subsection{Experimental plots}

Along a $2.5 \mathrm{~km}$ long transect running parallel to a narrow watershed, where pine and oak trees are evenly distributed in pure and mixed stands, we established a total of 12 circular experimental plots of $25 \mathrm{~m}$ diameter with four replicates per stand type (pine, oak and mixed stands). In addition, for the exploration and tracking of roots with the GPR, we established one $8.5 \mathrm{~m} \times 6 \mathrm{~m}$ plot with parallel transects (spaced $1 \mathrm{~m}$ ) to observe horizontal axis distribution of roots in a mixed stand and one concentric plot of five circular transects around an anchored Pinus cembroides tree (with 0.1, $0.3,0.5,1.0$ and $1.5 \mathrm{~m}$ distance between neighboring transects). To minimize radargrams signal noise we proceed precleaning the substrate surface from litter and twigs in all experimental plots. To monitor soil water potential $\left(\Psi_{\mathrm{s}}\right)$ at biweekly intervals, in September 2013, each circular plot was equipped with four (64 total) soil psychrometer sensors (PST-55, Wescor Inc., USA), which were inserted at 12 to $15 \mathrm{~cm}$ depth (depending on the depth of soil pockets) near tree trunks (Table 2). To determine electric resistivity, 72 geophysical electrodes coated with copper sulfate gel (24 for each stand type) were installed with northeastsouthwest orientation with $1 \mathrm{~m}$ inter-electrode spacing (along the slope). GPR radargrams were generated using a MALA RAMAC X3M GPR (shielded antennas)-ProEx system coupled to an inspection wheel. ERT tomograms were taken using the SYSCAL KID SWITCH-24 (IRIS instruments) with a 24-multi-electrode switch box.

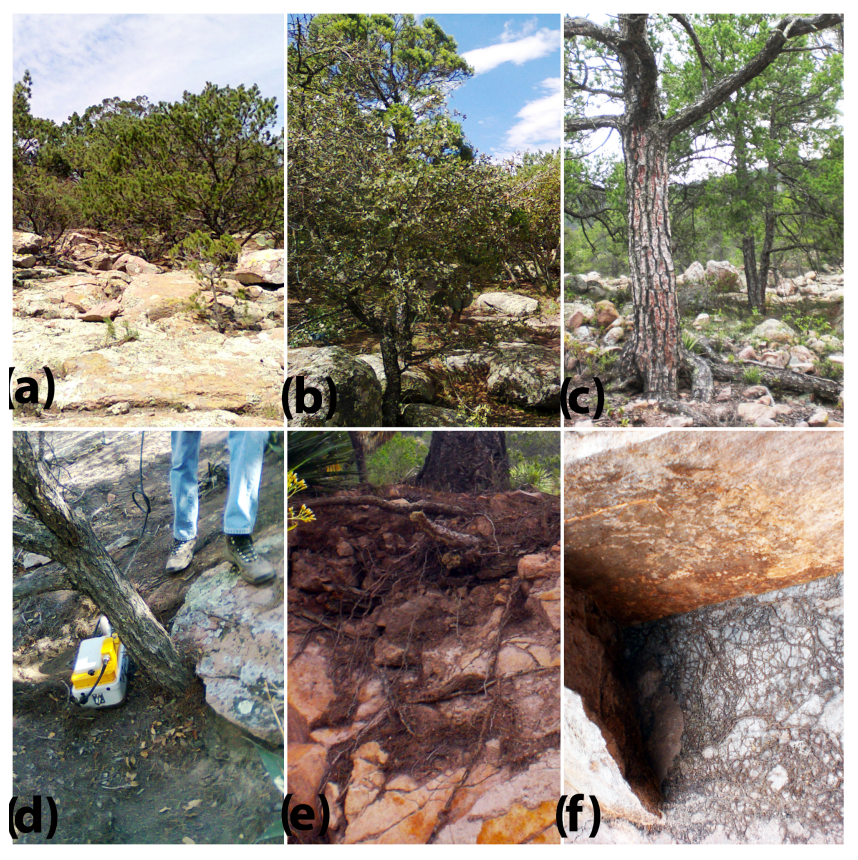

Figure 1. Site characteristics: (a) rhyolitic weathered bedrock in Pinus cembroides stands, (b) exfoliated rock in a pine-oak stand, (c) exposed coarse roots of $14 \mathrm{~cm}$ diameter in shallow rocky soils, (d) pine anchored under exfoliated rock, (e) high root density at the soil-bedrock interface and (f) fine roots colonizing a weathered bedrock layer.

\subsection{Principles of GPR}

GPR is an impulse radar system designed for shallow subsurface investigations from 1 to $25 \mathrm{~m}$ depth. A transmitting antenna of a certain frequency sends electromagnetic pulses from the soil surface through the soil matrix; a boundary layer is reflected when the transmitted pulse crosses two objects of different electromagnetic properties (Van Dam, 2014). Consequently, the reflected wave returns to the receiving antenna at ground level (or soil surface), which measures the reflected signal as a function of time (Butnor et al., 2001). Reflections and diffractions of electromagnetic waves may occur at boundaries between rock strata and objects that exhibit differences in electrical properties. Most soils and rocks have extremely low conductivity (about $<10^{-2} \mathrm{~S} \mathrm{~m}^{-1}$ ); thus the propagation of electromagnetic waves is mainly affected by electrical dielectric constants of soils and rocks (Heggy et al., 2003). Electric permittivity, $\varepsilon$, and electric conductivity, $\sigma$, are petrophysical parameters that determine the reflectivity of boundary layers and penetration depth. Generally, the reflection of an electromagnetic wave occurs at boundary layers and its strength is shown by the reflection coefficient, $r$, which is determined by (Blindow et al., 2007)

$r=\frac{\sqrt{\varepsilon_{1}}-\sqrt{\varepsilon_{2}}}{\sqrt{\varepsilon_{1}}+\sqrt{\varepsilon_{2}}}$ 
Table 2. Number of trees per stand and species included in the study of soil water potential $(n)$, as well as mean or tree diameter at breast height $(\mathrm{DBH})$, age estimated based on rings growth and total tree height of trees of Pinus cembroides and Quercus potosina at Sierra San Miguelito, San Luis Potosí, Mexico.

\begin{tabular}{lrrrr}
\hline Stand & $n$ & $\begin{array}{r}\text { DBH } \\
(\mathrm{cm})\end{array}$ & $\begin{array}{r}\text { Age } \\
(\text { years })\end{array}$ & $\begin{array}{r}\text { Tree height } \\
(\mathrm{m})\end{array}$ \\
\hline Pine (pure) & 16 & $18.701 \pm 2.49$ & $76.05 \pm 3.42$ & $4.863 \pm 0.74$ \\
Oak (pure) & 16 & $21.104 \pm 1.67$ & $83.17 \pm 3.21$ & $5.272 \pm 0.86$ \\
Pine (mixed) & 16 & $19.981 \pm 1.76$ & $84.20 \pm 4.88$ & $6.080 \pm 1.17$ \\
Oak (mixed) & 16 & $20.121 \pm 1.38$ & $82.06 \pm 2.82$ & $5.461 \pm 1.08$ \\
\hline
\end{tabular}

In this equation, $\varepsilon_{1}$ and $\varepsilon_{2}$ are the dielectric constants of roots and soil, respectively. Specifically, the contrast in dielectric constants between a root and the surrounding soil determines root radar reflectance (Fig. S3a). The larger the $r$ and the stronger the reflected wave at the boundary layer, the more the size and bow of the resulting hyperbola vary according to the amplitude of the reflected wave. The difference in dielectric permittivity of a root and its surrounding matrix forms a boundary, which then can be detected by a traveling electromagnetic wave; however, it varies in time and space as a function of soil (texture, water content) and root characteristics (size, depth, orientation, water content). When a traveling electromagnetic wave hits a boundary between materials with differing electromagnetic properties, such as dry soil and water-conducting roots, part of this wave is reflected (Raz-Yaseef et al., 2013), often producing hyperbolic patterns (Butnor et al., 2001). We have worked with waveform parameters of the time interval between zero crossings (ns) of maximum and minimum reflected waves (Guo et al., 2013).

\subsection{Principles of ERT}

ERT is a method that produces images of the variation of electrical resistivity in either two or three dimensions, below a line or grid of electrodes placed on the soil surface. ERT tomograms consist of a modeled cross-sectional plot of resistivity $\left(\Omega \mathrm{m}^{-1}\right)$ versus depth. The method is based on measurements of voltage differences between electrodes. This is a minimally invasive method, because it only requires inserting electrodes a few centimeters into the ground to create electrical contact. The resulting subsurface resistivity model depicts variations in the conductivity of electrical current in subsurface soils and rocks (Fig. S3b). Resistivity is the mathematical inverse of conductivity. The measured resistivity is a function of water content of the substrate (rock or soil), the chemical composition of pore water and the soil surface area/grain particle size distribution. The relations of these variables are summarized in Archie's law, an empirical equation of resistivity, $\rho\left(\Omega \mathrm{m}^{-1}\right)$, of rocks (König et al., 2007):

$\rho=\frac{a}{\phi^{m} S^{n}} \rho_{\mathrm{w}}$, where $\Phi$ (porosity) and $S$ (saturation factor) are fractions between 0 and $1, \rho_{\mathrm{w}}\left(\Omega \mathrm{m}^{-1}\right)$ is the resistivity of groundwater, and the parameters $a$ (tortuosity), $m$ (cementation factor), and $n$ (saturation exponent) are empirical constants that need to be determined for each study area.

\subsection{Data collection}

From October to December 2012, we examined the frequency, size, position and depth range of roots with 2.5 to $7.5 \mathrm{~cm}$ diameter in the top soil and under exfoliated rocks, using the GPR $500 \mathrm{MHz}$ shielded antenna and working with a $2.5 \mathrm{~m}$ depth window. To characterize the exfoliation of weathered bedrock soil, and to differentiate between the exfoliated rock base and potential root axes $(0.6$ to $4 \mathrm{~cm}$ diameter) underneath rocks, we used the GPR $800 \mathrm{MHz}$ shielded antenna, exploring at $1 \mathrm{~m}$ depth. Root identification in radargrams was a stepwise process; first, roots were recognized at locations where hyperbolas of reflected waves had relatively higher amplitudes compared to those in the surrounding area (Cui et al., 2011). Then, to determine the diameter and depth of these roots, the time interval between zero crossings (ns, time interval for maximum reflected wave) was extracted at the points of hyperbolas where roots had been identified previously. The detection frequency for the number of roots identified in the radar profile was calculated along each transect for five root diameter classes $(<3.0,3.0-4.0,4.0-5.0$, $5.0-6.0$ and $>6.0 \mathrm{~cm}$ ). Finally, for calibration purposes, individual roots (total of 76) were excavated to determine their depth and diameter in situ (Table 3, Fig. 2a).

Based on the assumption that electrical resistivity decreases with increasing water content (Nijland et al., 2010; Jayawickreme et al., 2014), we compared the spatial and temporal patterns of soil and bedrock moisture within and among forest stands. During an 8-month period, we generated 12 ERT tomograms (four for each stand type) during wet (October 2013 and February 2014) and dry (December 2013 and May 2014) ecohydrological periods. Here we present one representative profile for each forest stand. To relate $\Psi_{\mathrm{s}}$ data with ERT surveys, $\Psi_{\mathrm{s}}$ was measured at diurnal peaks of water stress (from 11 to $14 \mathrm{~h}$ ) every 2 weeks during an 8-month period (October 2013 to May 2014).

Finally, to trace short-term percolation responses and the progress of water profiles (March 2013) during the dry season, $15 \mathrm{~L}$ of water was injected into a shallow fracture of $35 \mathrm{~cm}$ length in an oak stand; $150 \mathrm{~min}$ later, we generated radar profiles along a $3.3 \mathrm{~m}$ transect running parallel to the slope with the $800 \mathrm{MHz}$ shielded antenna.

\subsection{Data processing and interpretation}

In field the following settings were used: time windows (400 ns), stacks (auto), sampling frequency $(1120 \mathrm{MHz})$, point distance $(0.001 \mathrm{~m})$ and velocity $\left(110 \mathrm{~m} \mu \mathrm{s}^{-1}\right)$. Raw GPR radargrams were processed with RadExplorer v1.42 
Table 3. Calibration and validation of roots (diameter and depth). This table represents the information extracted from a radargram of a pine-oak stand (Fig. S4).

\begin{tabular}{lrr|rr}
\hline \multirow{2}{*}{$\begin{array}{l}\text { Along } \\
\text { transect } \\
(\mathrm{m})\end{array}$} & \multicolumn{2}{c|}{ In situ } & \multicolumn{2}{c}{ GPR 500 MHz } \\
\cline { 2 - 5 } & $\begin{array}{r}\text { diameter } \\
(\mathrm{cm})\end{array}$ & $\begin{array}{r}\text { depth } \\
(\mathrm{cm})\end{array}$ & $\begin{array}{r}\text { diameter } \\
(\mathrm{cm})\end{array}$ & $\begin{array}{r}\text { depth } \\
(\mathrm{cm})\end{array}$ \\
\hline 1.35 & 2.6 & 7.4 & 2.8 & 7.2 \\
1.68 & 2.7 & 9.4 & 2.8 & 9.6 \\
3.18 & 2.5 & 15 & 2.4 & 15.2 \\
3.76 & 2.6 & 22.4 & 2.8 & 23.1 \\
3.98 & 3.7 & 8.5 & 3.6 & 8.9 \\
4.85 & 6.7 & 13.5 & 7.0 & 13.9 \\
5.35 & 2.9 & 21.5 & 3.2 & 22.2 \\
6.90 & 4.4 & 9.4 & 4.8 & 9.9 \\
7.12 & 2.8 & 13.8 & 2.6 & 14.2 \\
8.56 & 4.7 & 12.4 & 5.0 & 13.0 \\
10.78 & 2.5 & 13.0 & 2.8 & 13.4 \\
11.92 & 3.4 & 12.2 & 3.0 & 11.8 \\
\hline
\end{tabular}

software (Mala GeoScience Inc., USA) prior to interpretation. Post-acquisition processing of radar data is accomplished to reduce clutter, minimize the effects of multiple hyperbolic reflections and enhance the signal-to-noise ratio (Daniels, 1996). Filtering of radar data removed unwanted signals (noise) and corrected the position of reflectors on the radar record. The sequence of filter application depends on the accuracy of collected radargrams and the study's objective. Radar signals tend towards attenuation and loss with increasing depth during the propagation of soil. The greater the signal loss, the deeper the detection area. Thus, the signal data require dependent gain which compensates for amplitude reduction with depth (star point: 30 ). Prior to compensating for gain, in order to ensure that the mean of data is zero, the GPR data must remove the DC component, from the RAMAC XV Monitor (ProEx system - adjust signal position). Signal gain processing requires data with less noise, or the noise may be magnified. For each particular case, radargram processing follows specific procedures: data editing, correction of time zero, background removal filter, bandpass filtering and Stolt F-K migration (Butnor et al., 2012). In this study, for root exploration all radargrams were processed with the same range of filter values, because the whole study area had similar characteristics to a horizon of organic soil and weathered bedrock underneath. The correction of time zero, which is the start time that may not be detected precisely by the system, is corrected here to match with the antenna surface position and ensure the estimation of correct depths in the profile. The background removal filter, consists in eliminating parallel bands resulting from plane reflectors such as ground surface, leaf litter, soil horizons (when it comes to identifying roots in the soil), and bands of lowfrequency noise. We have largely removed noise by vertical high-pass filter and vertical low-pass filter (bandpass fil-
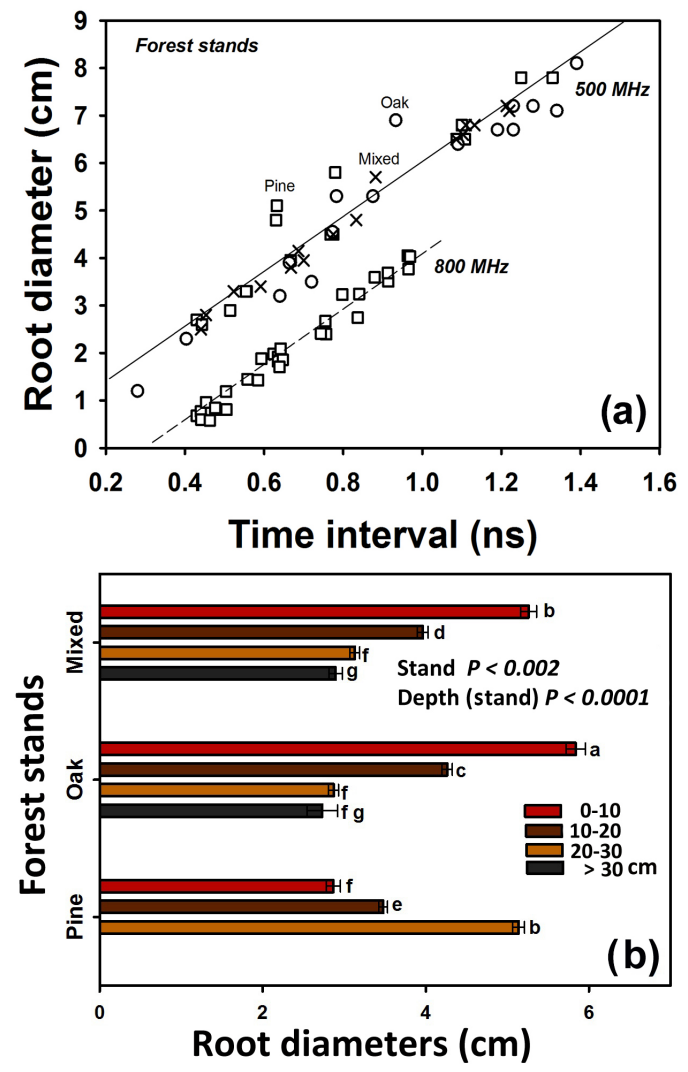

Figure 2. (a) Relationship between root diameter from different stands and time interval with zero crossing of detected roots, which were later used for calibration with both GPR systems: $500 \mathrm{MHz}$ shielded antenna $(n=48), P<0.0001$, and $800 \mathrm{MHz}$ shielded antenna $(n=28), P<0.0001$. (b) Average diameter of roots recorded with GPR for each of the three forest stand types at four depths. Different letters next to the bars indicate statistical differences among treatment combinations at a probability value of $P<0.05$.

tering: 700-1400 MHz) (Butnor et al., 2003; Dahboosh AlShiejiri, 2013). The Stolt F-K migration routine was used to correct for object position and collapsed hyperbolic reflections (diffracted waves) based on signal geometry (migration velocity: $12.8 \mathrm{~cm} \mathrm{~ns}^{-1}$ ) (Doolittle and Butnor, 2009). The waveform parameter of the time interval between zero crossings (ns) of the maximum reflected wave was extracted at the points of root detection in the radar profiles and calculated using RadExplorer v1.42 software.

Electrical resistivity tomography was conducted using a Wenner-switch array. Resistivity values were corrected for the effect of temperature, based on the temperature recorded by the closest soil psychrometer sensor at a given depth for each resistivity value, and on the Campbell equation (Campbell et al., 1949) as suggested by Samouëlian et al. (2005):

$\rho=\rho T[1+\alpha(T-25)]$, 
where $T$ corresponds to temperature $\left({ }^{\circ} \mathrm{C}\right), \rho T$ is the electrical resistivity measured at temperature $T\left(\Omega \mathrm{m}^{-1}\right), \rho$ is the electrical resistivity at the reference temperature of $25^{\circ} \mathrm{C}$ $\left(\Omega \mathrm{m}^{-1}\right)$, and $\alpha$ refers to a correction factor equal to 0.0202 .

Inversion and forward simulations were performed with RES2DINV software (Geotomo software) for later manipulation of data files with the ArcMap module applying an empirical Bayesian kriging method (ArcGIS Desktop; ESRI 2011). For more details on the softwares and algorithms used see Krivoruchko (2012) and Loke (2004).

\subsection{Statistical analysis}

Nested two-way analysis of variance was used to examine differences in root diameter. The model included two factors, forest stand with three levels (pure and mixed pine and oak stands; fixed effect) and soil depth with four levels (10, 20, 30 and $>30 \mathrm{~cm}$; nested effect); in the case of significant interactions we conducted Tukey's post hoc mean comparison test. We ran Type I regression analyses to examine the relationships between root diameter and time interval between zero crossings (ns) for both frequency antennas to calibrate the method. Polynomial quadratic regression analyses were conducted to examine the relationship between $\Psi_{\text {soil }}(\mathrm{MPa})$ and resistivity $\left(\Omega \mathrm{m}^{-1}\right)$. Prior to statistical analysis we applied the Shapiro-Wilk test to examine normality of the residuals. All statistical analyses were run in SAS University Edition (free statistical software).

\section{Results}

All geophysical images helped interpret the spatial distribution of tree roots in soils and weathered bedrock, as well as that of rocky soil characteristics. However, some difficulties in the interpretation of raw radargrams (unfiltered radar profiles) included noise and ghost areas caused by characteristics of organic and rocky soils. Nevertheless, radargrams indicated clear hyperbolic reflections that corresponded to the position of tree roots (validated with field excavations) at certain depths (Fig. S3a). ETR tomogram results (Fig. S3b) for the top $50 \mathrm{~cm}$ helped identify areas of greatest drainage (200$450 \Omega \mathrm{m}^{-1}$ ) and fracturation (400-700 $\Omega \mathrm{m}^{-1}$ ). ETR tomogram outputs of RES2DINV software did not reveal the exfoliated rock that occur in the study area.

\subsection{GPR detection of tree roots and diameter estimation}

We examined the relationships between root diameter and time interval between zero crossings (ns) using $500 \mathrm{MHz}$ signals $\left(P<0.0001, R^{2}=0.93\right.$, Table 4 , Fig. $\left.2 a\right)$. With this shielded antenna, we detected roots as fine as $2.5 \mathrm{~cm}$ diameter and as coarse as $7.5 \mathrm{~cm}$ in different tree stands. In pure pine stands, the finest roots $(2.5-3 \mathrm{~cm})$ were preferentially located in the top $10 \mathrm{~cm}$ of the organic soil, while coarse diameter roots occurred mostly at $30 \mathrm{~cm}$ depth (Table 5, Fig. 2b). In contrast, in pure oak stands root diameter decreased with increasing soil depth (Fig. 2b). Also, in mixed stands, deeper roots had overall smaller diameters (Fig. 2b) than roots in shallow soils. It is important to remark that in pure pine stands no roots occurred below $30 \mathrm{~cm}$ depth. Figure S4 depicts a typical radargram generated with a $500 \mathrm{MHz}$ shielded antenna after having applied bandpass filtering and the background removal filter. The GPR radargram of a mixed forest stand revealed the highest aggregation of coarse roots near the tree bases and their adjacent areas, as well as a high heterogeneity of root diameter distribution between trees (Fig. S4). Radargrams also revealed a clear boundary layer between the soil and the rocky substrate (Fig. S4, continuous line) and soil pockets (Fig. S4, dotted line). These soil profiles were validated in situ.

In a mixed stand, a two-dimensional radargram sequence was generated with the $500 \mathrm{MHz}$ shielded antenna in a $8.5 \mathrm{~m} \times 6 \mathrm{~m}$ horizontal tracking quadrant; both pine and oak roots (different uppercase letters in Fig. 3) were validated in situ. For this serial root mapping consisting of seven sequential radargrams, we identified a total of 386 roots in their horizontal position. Diameters of single roots were highly variable $(2.5-6 \mathrm{~cm})$, as well as signal outputs (hyperbolas) for deep roots $(5-30 \mathrm{~cm})$. With this sequential series of radargrams, we could track the horizontal distribution of single root axes (for instance root "B" in the different radargrams) (Fig. 3b-g). We found high variation in root diameters along a $6 \mathrm{~m}$ transect (root diameters in radar profile $\mathrm{a}=6.5, \mathrm{~b}=4.8$, $\mathrm{c}=5.2, \mathrm{~d}=5.8, \mathrm{e}=6.4, \mathrm{f}=4.6, \mathrm{~g}=3.8 \mathrm{~cm}$ ) in accordance with the size of signal amplitude (in radar profile $\mathrm{a}=1.16$, $\mathrm{b}=0.78, \mathrm{c}=0.84, \mathrm{~d}=0.94, \mathrm{e}=1.09, \mathrm{f}=0.73, \mathrm{~g}=0.61 \mathrm{~ns})$. Roots with larger diameters had higher signal amplitudes, whereas smaller diameter roots had lower amplitudes.

We identified pine trees anchored under exfoliated rocks by applying $800 \mathrm{MHz}$ shielded antenna along concentric transects around a tree and after adopting background removal routines (Fig. 4). We observed a significant relationship between root diameter and time interval between zero crossings using $800 \mathrm{MHz}$ signals $\left(P<0.0001, R^{2}=0.98\right.$, Table 4, Fig. 2a). The radargram also revealed (Fig. 4b, uppercase letters) roots under exfoliated rocks, which were then used to calibrate the radargram. This technique allowed us to differentiate between the base of exfoliated rocks (about $35 \mathrm{~cm}$ deep) and the presence of thin roots underneath that bedrock ( 0.6 to $4 \mathrm{~cm}$ in diameter). In the transect at $50 \mathrm{~cm}$ distance from the trunk, three hyperbolas were reflected, suggesting root presence under the exfoliated rocks (Fig. 4b). By increasing transect length, the number of reflected hyperbolas increased under the bedrock (e.g., transect at $100 \mathrm{~cm}$ distance from tree base) and the rock limits, permitting tracking of root elongation in shallow rocky soils. Also, it was possible to match a high signal amplitude with a pine tree anchored beneath an exfoliated rock (Fig. 4b, letter "B") and its associated lateral roots (Fig. 4b, arrows). In spite of filter- 
Table 4. Intercepts, slopes, regression coefficients and observed probabilities of linear regressions between root diameter (cm) and time interval (ns) which were used for calibration with both GPR systems for each sample type.

\begin{tabular}{lrlrrrrr}
\hline Type of sampling & GPR systems & Stand & Intercept \pm 1 SE & Slope \pm 1 SE & $R^{2}$ & $P$ \\
\hline Radial & $500 \mathrm{MHz}$ & Pine & $0.3610 \pm 0.3751$ & $5.7890 \pm 0.4473$ & 0.92 & $<0.0001$ \\
Radial & $500 \mathrm{MHz}$ & Oak & $-0.0013 \pm 0.4234$ & $5.7736 \pm 0.4309$ & 0.94 & $<0.0001$ \\
Radial & $500 \mathrm{MHz}$ & Mixed & $-0.0536 \pm 0.1506$ & $6.0195 \pm 0.1712$ & 0.98 & $<0.0001$ \\
Concentric & $800 \mathrm{MHz}$ & Pine & $-2.0910 \pm 0.1273$ & $6.2450 \pm 0.1839$ & 0.98 & $<0.0001$ \\
\hline
\end{tabular}

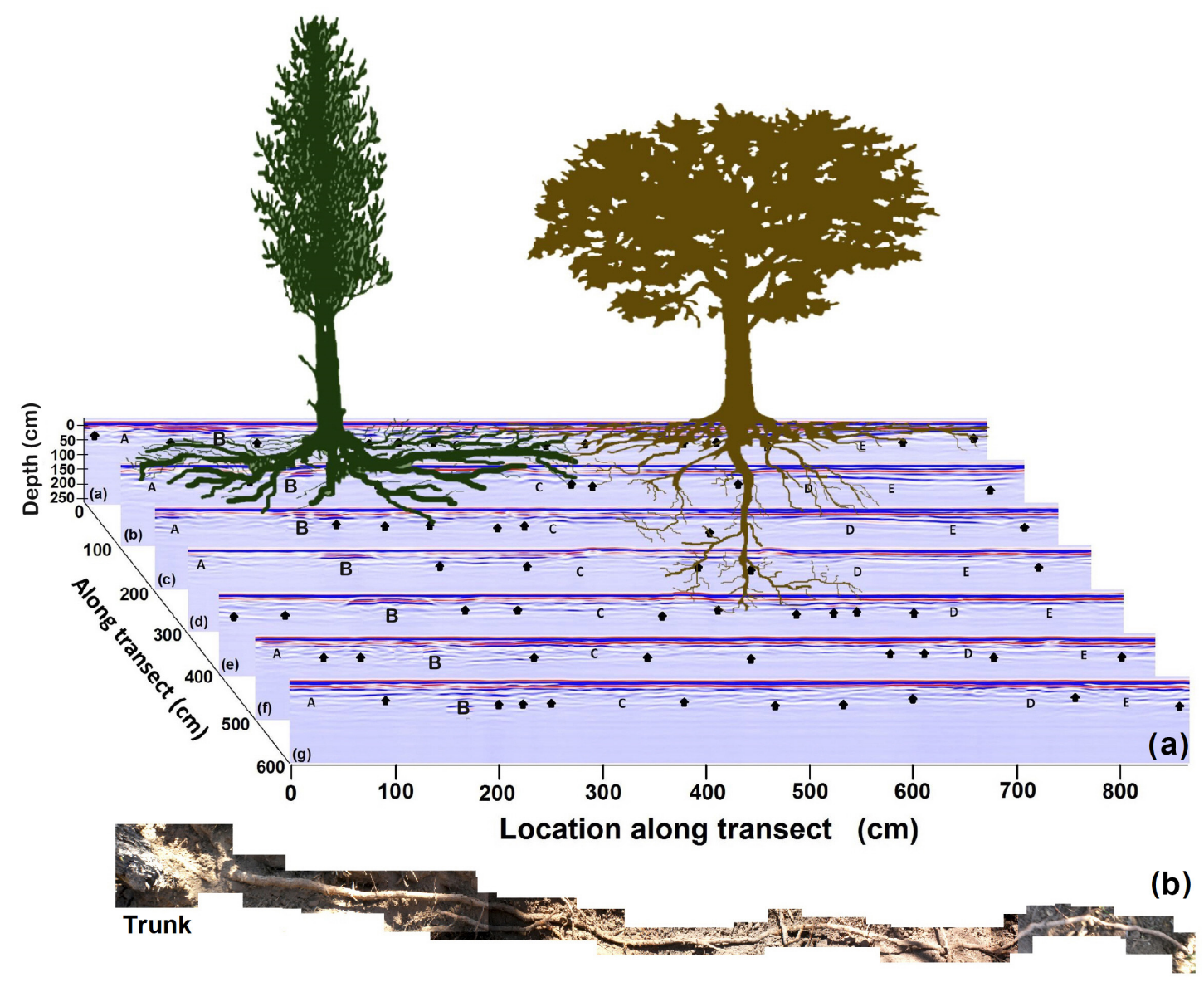

Figure 3. Mapping of root systems with GPR showing the potential for radargrams to represent an approximation of horizontal root distribution. (a) Two-dimensional radargram sequence obtained with the $500 \mathrm{MHz}$ shielded antenna performing seven parallel transects of $8.5 \mathrm{~m}$, spaced $1 \mathrm{~m}$ apart. In each radargram, cross sections of roots were identified and then their diameters estimated. By linking root reflectors in neighboring GPR radargrams, the orientation and length of each single root were obtained (same letters). Arrows and letters in different GPR radargrams correspond to reflections from the same roots; these were used for calibration in situ. With the $500 \mathrm{MHz}$ shielded antenna, the position, size and depth of roots with 2.5 to $7.5 \mathrm{~cm}$ diameter were estimated. The image shows an example of the position of a pine and oak tree and the potential application of the GPR tool for spatially explicit root distribution studies. (b) Horizontal elongation of a root axis of Pinus cembroides marked with the letter "B" in panel (a).

ing routines, it is impossible to completely remove all noise sources in all radargrams; for example, there was some residual noise associated with leaf litter accumulation under and on top of exfoliated rocks - however, in situ verification confirmed that radargrams spotted primarily tree roots.

\subsection{Distribution of roots and subsurface resistivity imaging}

ERT tomograms of different forest stands revealed a clear horizontally layered structural organization of weathered rock with exfoliation (Fig. 5). The tomograms at $0-2 \mathrm{~m}$ depth showed a wide range of resistivity values with max- 


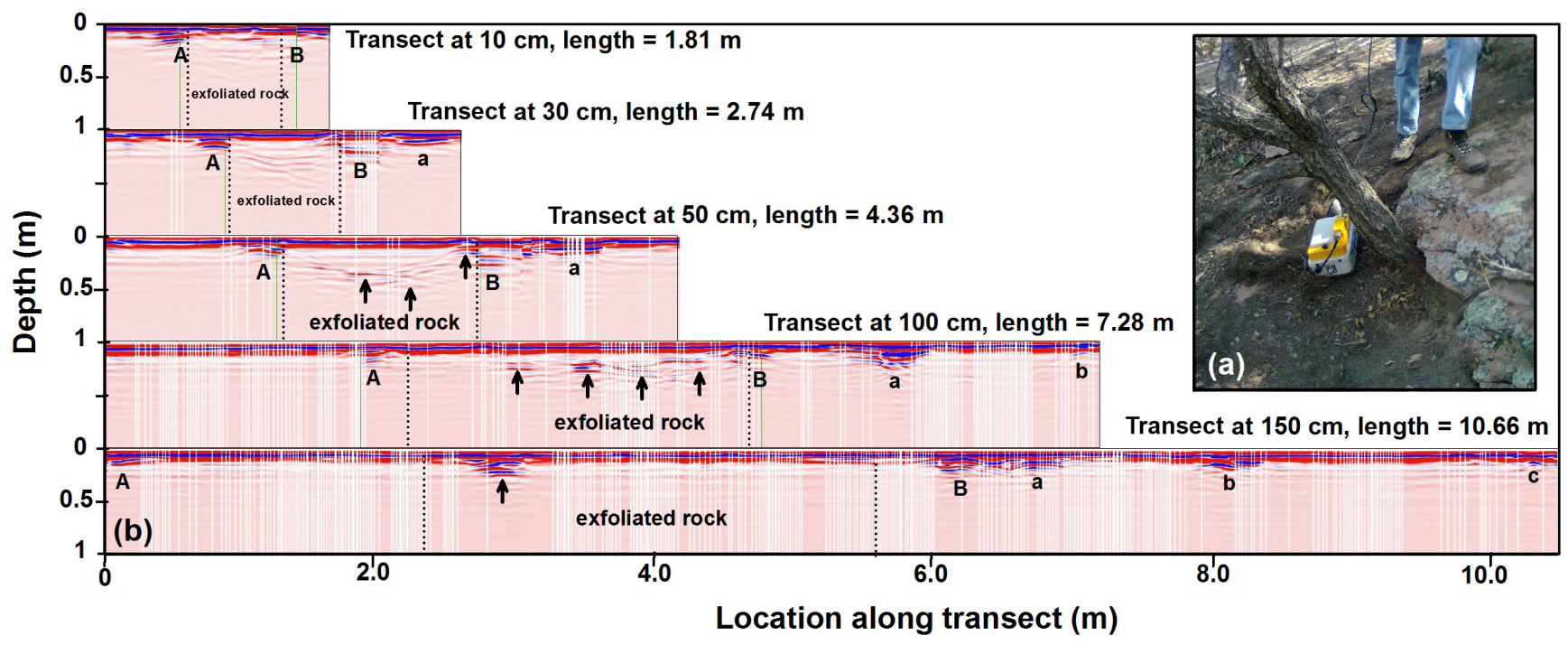

Figure 4. Concentric transects used to detect and track lateral root proliferation with GPR. (a) In situ photography showing a Pinus cembroides root anchored in exfoliated rock and the GPR system with the $800 \mathrm{MHz}$ shielded antenna. Five concentric transects were established around the tree with $0.1,0.3,0.5,1.0$ and $1.5 \mathrm{~m}$ distance between neighboring transects. The radius of each transect varied from 0.29 to $1.7 \mathrm{~m}$. (b) Corresponding GPR radargrams of different transect lengths. Same letters in different GPR radargrams indicate examples of reflections from the same roots; uppercase letters indicate roots used for calibration. Arrows indicate root presence under exfoliated rocks.

Table 5. Nested two-way analysis of variance to examine root diameter differences observed among the combination of four soil depths $(10,20,30$ and $>30 \mathrm{~cm})$ and three forest stands (Pinus cembroides, Quercus potosina and mixed forest) in a semiarid forest ecosystem in central-north México.

\begin{tabular}{lrrr}
\hline Effect & df & $F$ & $P$ \\
\hline Stand & 2 & 8.51 & 0.0002 \\
Depth (stand) & 8 & 184.98 & $<0.0001$ \\
\hline
\end{tabular}

ima $>1000 \Omega \mathrm{m}^{-1}$ observed at tomogram bottoms and a minimum between 250 and $650 \Omega \mathrm{m}^{-1}$ at the surface horizons. In the upper horizons $(<0.5 \mathrm{~m})$, the observed low resistivities $\left(<450 \Omega \mathrm{m}^{-1}\right)$ corresponded to islands of higher root densities beneath vegetation patches and were associated with water extraction zones; high resistivities $\left(>450 \Omega \mathrm{m}^{-1}\right)$ coincided with bedrock outcroppings. Considering vertical distributions of pine and oak roots (Fig. S4), ERT tomograms clearly matched root distribution to species-specific vegetation cover at the measurement points.

Following seasonal drought (December 2013 to May 2014), ERT profiles of all stands exhibited increasing resistivity between 0 and $1 \mathrm{~m}$ depth (Fig. S5), which was likely attributed to soil drying as a consequence of both root water uptake and soil evaporation. Thus, in the top meter, we observed the largest spatial variation in bedrock moisture content ranging from 250 to $1450 \Omega \mathrm{m}^{-1}$ ( $\Psi_{\mathrm{s}}=-0.5$ to $-24.5 \mathrm{MPa}$ ). By visual assessment, both mixed and pure oak stands showed highest moisture content in all four monitored periods (Fig. S5e-1). Pure pine stands preferentially occurred on sites with deepest soils (up to $60 \mathrm{~cm}$ ), while pure oak stands anchored mostly on exfoliated rocks. Mixed stands had a combination of both abiotic site characteristics.

Soil resistivity and soil water potential were negatively related considering all observations from the different stands $\left(R^{2}=0.95 ; P<0.0001\right.$, Fig. S6). Thus, as resistivity increased, $\Psi_{\mathrm{s}}$ dropped; this trend was apparent for resistivity values up to around $750 \Omega \mathrm{m}^{-1}$ being proportional to almost $-6 \mathrm{MPa}$.

\subsection{Fracturing as a secondary water supply to forest trees}

In the dry season, upon water injection into a rock fracture next to an oak tree base growing on exfoliated rock (Fig. 6a), we observed a response signal in the form of a wave amplitude equivalent to those observed underneath vegetation patches (Fig. 6b). Radargrams showed a clear infiltration horizon at approximately $50 \mathrm{~cm}$ depth. The signal appeared 150 min after water injection; while it was not homogeneous for all vegetation patches, because of different root densities and other microsite differences, we could detect a signal for horizontal displacement of water up to $3 \mathrm{~m}$ distance from where it was injected.

\section{Discussion}

In semiarid environments, forest ecosystems that develop on young volcanic bedrock and poorly developed soils face 


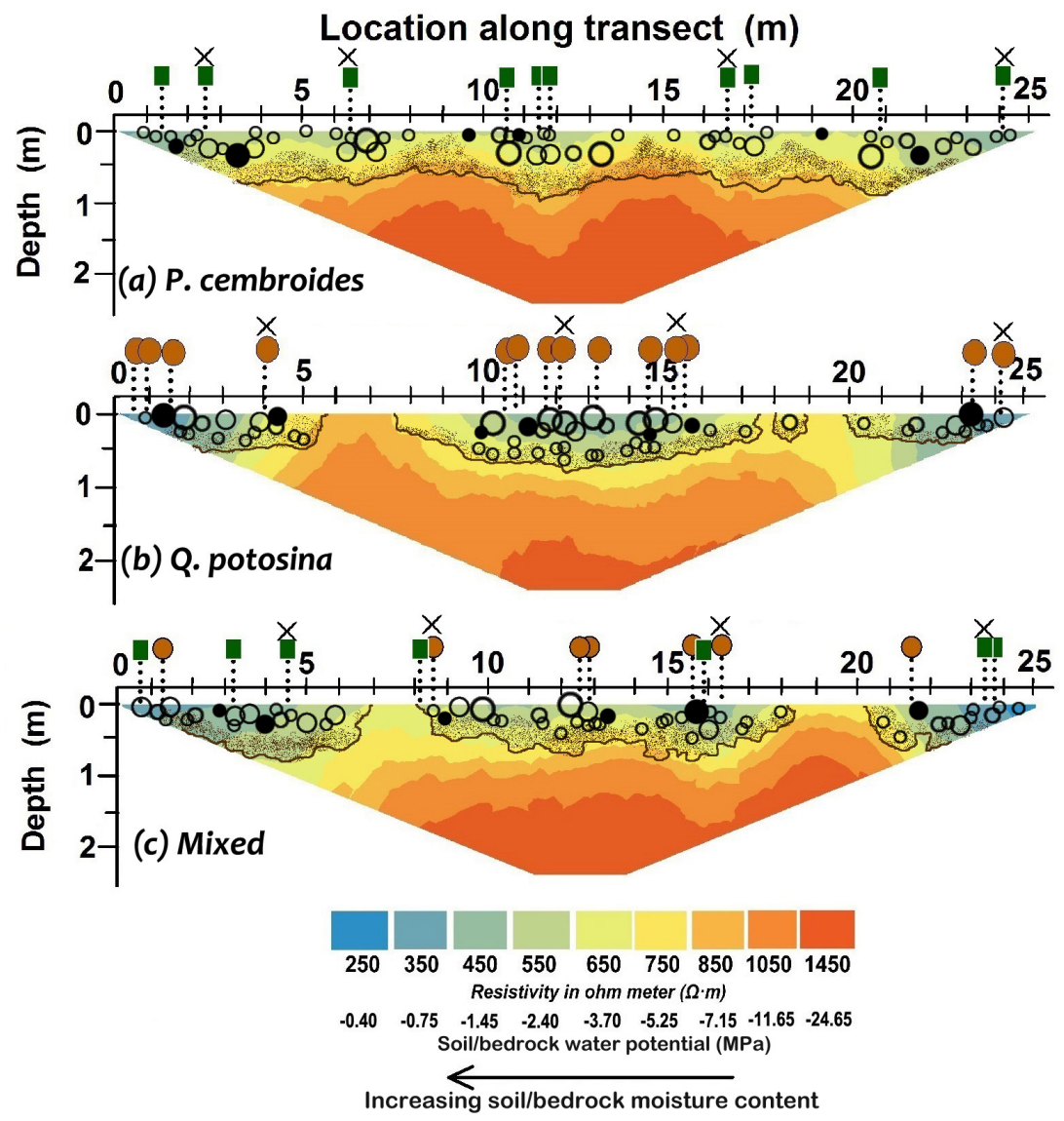

Figure 5. ETR tomograms in (a) Pinus cembroides, (b) Quercus potosina and (c) pine-oak forest stands. ERT profiles showed a relationship between the position of roots, low soil resistivity (greater water availability) and greater bedrock fracturing. The top soil corresponds to the first $20-25 \mathrm{~cm}$ layer, the intermediate layer includes soil pockets and rock fractures and is depicted by the dotted strip along the radargram and the fresh bedrock begins underneath the solid line. Circles of different size depict roots of different diameter size (see figure legend in Fig. S4). Black circles indicate roots that were used for GPR calibration. Trees marked with X indicate the presence of soil psychrometer sensors.

two independent growth limitations: (1) highly variable precipitation as well as increasing frequency of droughts and (2) extremely low water storage capacity of soils. Hence, insight into the distribution of different tree root types at the soil-bedrock interface and the spatiotemporal availability of water is fundamental for understanding tree ecophysiology, tree population dynamics, tree species interactions and forest ecosystem functioning. A lack of instruments and technology to study belowground root ecology has delayed scientific advances in forest ecosystem ecology in semiarid regions. However, with interdisciplinary efforts and the employment of geophysical tools and standard methods in ecosystem science (e.g., use of natural abundance and tracer stable isotopes), potentially great advances may be achieved in our understanding of the underlying geoecohydrological mechanisms that may explain tree species coexistence in extreme water-limiting environments (Rodriguez-Robles et al., 2015). Here, we demonstrate the enormous potential of applying geophysical tools to examine non-destructively and in realtime soil-bedrock-water and root characteristics.

With the use of GPR, we clearly detected pine and oak roots with diameters ranging between 0.6 and $7.5 \mathrm{~cm}$ under natural soil conditions (root diameters of 2.5 to 7 and 0.6$4 \mathrm{~cm}$ with the 500 and $800 \mathrm{MHz}$ shielded antennas, respectively; Figs. 2 and S4). Typically, belowground studies using GPR are carried out in sites with homogeneous soils, such as forest plantations, gardens, parks, backyards, crop fields, or under highly controlled conditions (Ow and Sim, 2012; Cermak et al., 2000; Cox et al., 2005; Dannoura et al., 2008; Zenone et al., 2008; Zhu et al., 2014) to reduce the difficulty in detecting and interpreting the origin of reflected signals (hyperbolic). In our case, it was fundamental to use high- and low-frequency antennas, as they gave valuable complementary information on these complex shallow rocky soils over volcanic bedrock. With the $500 \mathrm{MHz}$ shielded antenna, we could differentiate between and characterize a series of vertical substrate layers, whereas with the $800 \mathrm{MHz}$ shielded an- 


\section{Location along transect $(\mathrm{cm})$}

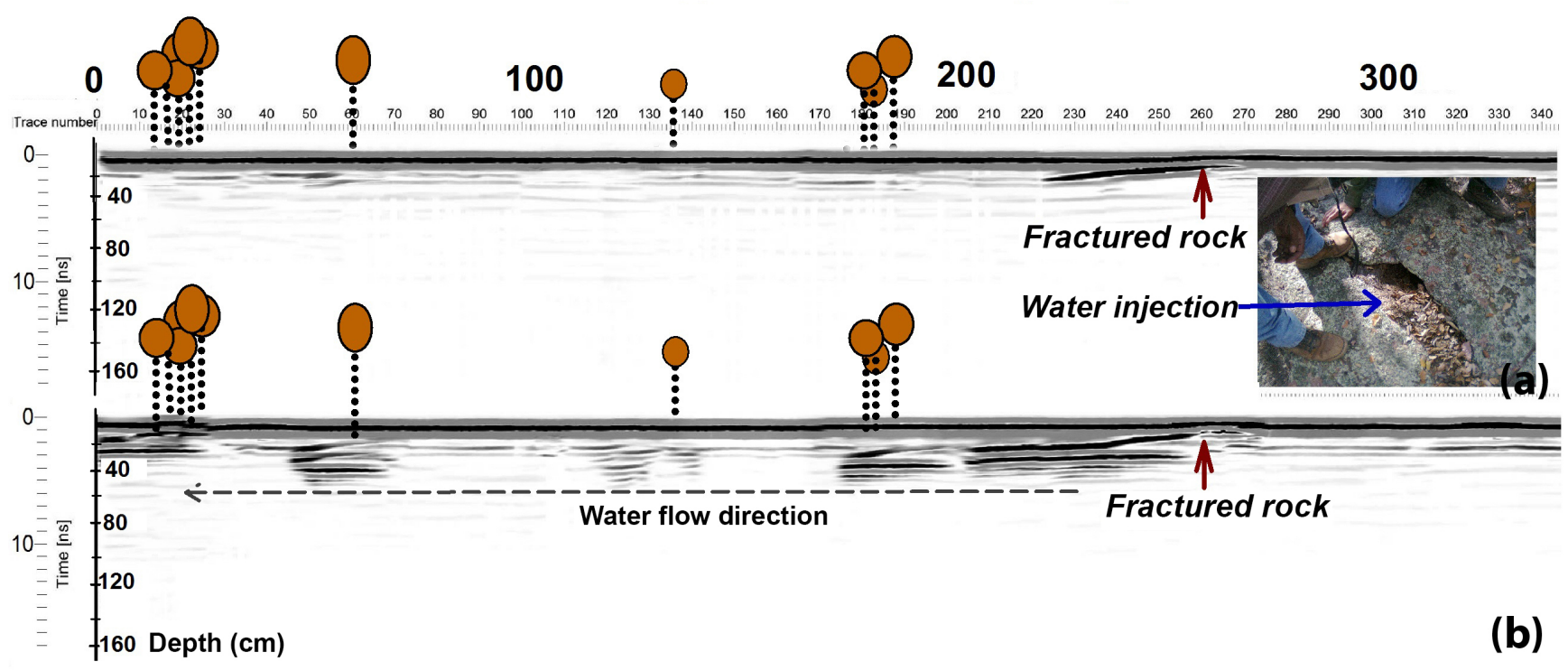

Figure 6. GPR radargrams showing how oak roots are preferentially located in fractured rocks where the probability of water accumulation is high. (a) GPR radargram in dry conditions. (b) GPR radargram $150 \mathrm{~min}$ after the injection of $15 \mathrm{~L}$ of water in a rock fracture. In the radargrams filters were applied to highlight areas of interest. Inserted photo: rock fracture, where water was injected.

tenna we could locate thin roots underneath exfoliated rocks. However, with the $800 \mathrm{MHz}$ shielded antenna, detection efficiency of fine roots decreased in sites with high litter accumulation of fresh pine needles on exfoliated rocks (Fig. 4). Similar difficulties for GPR interpretation had been mentioned previously; for instance Hirano et al. (2009) reported that soil water content may greatly limit the detection of reflected waves originating from roots. In October 2013 (a wet month), we carried out an experiment with the GPR $500 \mathrm{MHz}$ shielded antenna to examine the wetness effect in one of the experimental plots. Under high soil moisture content, we did not get a signal from the roots at this site, most likely because the signal wavelength gets lost by undetected changes in the dielectric properties between roots and soil (material interface) (Guo et al., 2013; Hirano et al., 2012; Butnor et al., 2009). Although our GPR survey was carried out in the dry period, we were still facing some difficulties to accurately differentiate between hyperboles deriving from different yet overlapping roots. The experiment of local water injection in a rock fracture (Fig. 6) greatly helped to clearly identify and separate the hyperbolas (roots) in the radargram.

\section{Dynamics of water inside of weathered bedrock and spatial distribution of roots}

In forests colonizing shallow soils and impermeable volcanic bedrock, water availability largely depends on the soilweathered bedrock interaction (Fig. 5). In one particular case, water of an accumulated $87 \mathrm{~mm}$ rain event occurring in February, infiltrated and percolated down to only $50 \mathrm{~cm}$ depth (Fig. S5c, k). Although volcanic bedrock is characterized by low permeability, rock fracturation may contribute to what can be called "secondary substrate porosity" in impermeable bedrock, thereby allowing water flow and storage within volcanic bedrock (Carrillo-Rivera et al., 1996). The analysis of ERT tomograms revealed a clear detachment of rock layers (exfoliation) (Fig. 5) and the presence of soil pockets (Fig. 5b, located at $18.4 \mathrm{~m}$ of the transect), which are both formations that potentially favor water storage. These conditions appear to promote the establishment and anchorage of trees under otherwise highly limiting soil water conditions. Several studies have reported that trees can get established in rock fractures (mainly calcic and permeable bedrock) (Estrada-Medina et al., 2010; Poot and Lambers, 2008) and that they locate their roots inside of this permeable material to exploit stored water (Schwinning, 2013; Querejeta et al., 2007). The combination of tomogram and radargram images (Fig. 5) revealed distinctive microsites in this shallow layer of weathered bedrock suitable for tree establishment and the formation of vegetation patches. Also, our results suggest that oak and pine might exhibit complementary strategies to access different water sources. Oak distributes its finest roots in both the soil organic layer and in the soil-weathered bedrock interface (Figs. $2 b, 5 b$ ). This rooting pattern may enable oak to access water retained in weathered bedrock during the dry periods (Fig. 6). Pine, in contrast, absorbs water exclusively from shallow surface soil (Figs. 2b, 5a). Species-specific differences and preferential horizontal (pine) and vertical (oak) root distribution in these geohy- 
drological niches suggest the two species coexist in these ecosystems (Rodriguez-Robles et al., 2015). Additional studies are needed to confirm this possibility.

Our assay of injecting water into a rock fracture in the dry period showed that oak roots responded rapidly, i.e., within $150 \mathrm{~min}$, to a short-term water pulse, which moved $300 \mathrm{~cm}$ laterally, suggesting some sort of channel-type connection between fractures and exfoliated rocks (Fig. 6). Hence, exfoliated rocks may play key bi-functional ecological role: they support tree anchorage (Fig. 4a) and serve as vital water entry, reservoir and distribution points during dry periods (Fig. 6b). Root anchorage in exfoliated rocks at this site can be considered as a survival strategy, since trunks and horizontal roots located below exfoliated rocks obtain physical support, which cannot be provided otherwise in these particularly shallow soils (Fig. 5).

\section{Conclusion}

This study highlights thus far underexplored yet potentially extremely powerful tools of geophysical imaging in forest ecohydrology. They allow in situ non-destructive estimation of a wide range of tree root diameters, with $0.6 \mathrm{~cm}$ as the highest resolution of diameter and the location of short-term and long-term water reservoirs in a complex soil-rock terrain. Furthermore, non-invasive mapping of GPR and ERT provides detailed field-level information of geohydrological characteristics of the soil-weathered bedrock interface, which were traditionally assessed with coring and excavation methods. This study demonstrates that the application of ERT and GPR has an enormous potential to capture belowground spatial and temporal characteristics of roots and soil moisture distribution at the field scale.

While these tools offer many advantages for the study of belowground in situ aspects of ecosystems and RadExplorer and ArcGis software allow powerful image processing and manipulation of radargrams and tomograms, we want to highlight the major limitations encountered in this study: certain field conditions (e.g., leaf litter, weathered bedrock regolith) (i) impede or reduce the detection potential and quantification of coarse roots when using the GPR $500 \mathrm{MHz}$ shielded antenna, and (ii) they also reduced the capability of the GPR $800 \mathrm{MHz}$ shielded antenna to delineate reflection signals emitted by roots; (iii) an increase in soil moisture may decrease the electromagnetic gradient between roots and soil, such that reflected signals get considerably weakened, which makes root delineation more difficult under wet conditions; and (iv) contact resistance problems with electrodes in the ERT survey become more difficult in assessing moisture content in the soil-bedrock, in particular during dry periods and high temperatures. We minimized these problems by pre-cleaning the surface of litter and twigs (points $\mathrm{i}$ and ii) and by applying copper sulfate gel in the inserted electrodes (point iii).
Geophysical images are highly valuable and promising tools to advance our understanding of the coupled nature of geoecohydrological patterns and processes by linking belowground geophysical structures with soil/bedrock hydrological characteristics and root ecology.

Data availability. Data can be provided on request to the authors.

\section{The Supplement related to this article is available online at https://doi.org/10.5194/bg-14-5343-2017-supplement.}

Author contributions. URR, TA and JARL planned and designed the research and executed the field experiments. URR, TA, EHS and EAY analyzed the data and wrote the manuscript.

Competing interests. The authors declare that they have no conflict of interest.

Acknowledgements. We thank Alejandro Cruz Rosas Palafox for technical advice on the use of the ERT equipment. We thank the Applied Geosciences Division at IPICYT for providing access to geophysical instruments and tools. Ulises Rodríguez-Robles acknowledges the National Council for Science and Technology of Mexico (CONACyT) for the scholarship no. 332356 granted to pursue his $\mathrm{PhD}$ degree. This work was supported by grants given to Tulio Arredondo from CONACYT, nos. 220788 and 224368.

Edited by: Anja Rammig

Reviewed by: Victor Resco de Dios and two anonymous referees

\section{References}

Adepelumi, A. A. and Fayemi, O.: Joint application of ground penetrating radar and electrical resistivity measurements for characterization of subsurface stratigraphy in Southwestern Nigeria, J. Geophys. Eng., 9, 397-412, https://doi.org/10.1088/17422132/9/4/397, 2012.

Aditama, I. F., Widodo, Setiawan, T., Bijaksana, S., and Sanny, T. A.: Use of electrical geophysical methods for supporting agricultural practices, AIP Conf. Proc., 1861, 030027, https://doi.org/10.1063/1.4990914, 2017.

Anderegg, L. D. and HilleRisLambers, J.: Drought stress limits the geographic ranges of two tree species via different physiological mechanisms, Glob. Change Biol., 22, 1029-1045, https://doi.org/10.1111/gcb.13148, 2016.

Andrews, M. Y., Ague, J. J., and Berner, R. A.: Trees and weathering: Chemical alteration of bedrock and soils in the Yale-Myers Forest, Northeastern Connecticut, Abstr. Pap. Am. Chem. S., 229, U893-U893, 2005. 
Barton, C. V. M. and Montagu, K. D.: Detection of tree roots and determination of root diameters by ground penetrating radar under optimal conditions, Tree Physiol., 24, 1323-1331, 2004.

Beff, L., Günther, T., Vandoorne, B., Couvreur, V., and Javaux, M.: Three-dimensional monitoring of soil water content in a maize field using Electrical Resistivity Tomography, Hydrol. Earth Syst. Sci., 17, 595-609, https://doi.org/10.5194/hess-17595-2013, 2013.

Blindow, N., Eisenburger, D., Illich, B., Petzold, H., and Richter, T.: Ground Penetrating Radar, in: Environ. Geol., Springer Berlin Heidelberg, Germany, 283-335, 2007.

Borden, K., Isaac, M., Thevathasan, N., Gordon, A., and Thomas, S.: Estimating coarse root biomass with ground penetrating radar in a tree-based intercropping system, Agroforest. Syst., 88, 1-13, https://doi.org/10.1007/s10457-014-9722-5, 2014.

Brooks, J. R., Meinzer, F. C., Coulombe, R., and Gregg, J.: Hydraulic redistribution of soil water during summer drought in two contrasting Pacific Northwest coniferous forests, Tree Physiol., 22, 1107-1117, 2002.

Burgess, S. S. O. and Bleby, T. M.: Redistribution of soil water by lateral roots mediated by stem tissues, J. Exp. Bot., 57, 32833291, https://doi.org/10.1093/jxb/erl085, 2006.

Butnor, J. R., Doolittle, J. A., Kress, L., Cohen, S., and Johnsen, K. H.: Use of ground-penetrating radar to study tree roots in the southeastern United States, Tree Physiol., 21, 1269-1278, 2001.

Butnor, J. R., Doolittle, J. A., Johnsen, K. H., Samuelson, L., Stokes, T., and Kress, L.: Utility of ground-penetrating radar as a root biomass survey tool in forest systems, Soil Sci. Soc. Am. J., 67, 1607-1615, 2003.

Butnor, J. R., Pruyn, M. L., Shaw, D. C., Harmon, M. E., Mucciardi, A. N., and Ryan, M. G.: Detecting defects in conifers with ground penetrating radar: applications and challenges, Forest Pathol., 39, 309-322, https://doi.org/10.1111/j.14390329.2009.00590.x, 2009.

Butnor, J. R., Barton, C., Day, F. P., Johnsen, K. H., Mucciardi, A. N., Schroeder, R., and Stover, D. B.: Using Ground-Penetrating Radar to Detect Tree Roots and Estimate Biomass, in: Measuring Roots: An Updated Approach, edited by: Mancuso, S., Springer Berlin Heidelberg, Germany, 213-245, 2012.

Campbell, R. B., Bower, C. A., and Richards, L. A.: Change of electrical conductivity with temperature and the relation of osmotic pressure to electrical conductivity and ion concentration for soil extracts, Soil Sci. Soc. Am. J., 13, 66-69, 1949.

Carrillo-Rivera, J. J., Cardona, A., and Moss, D.: Importance of the vertical component of groundwater flow: a hydrogeochemical approach in the valley of San Luis Potosi, Mexico, J. Hydrol., 185, 23-44, https://doi.org/10.1016/S00221694(96)03014-4, 1996.

Cermak, J., Hruska, J., Martinkova, M., and Prax, A.: Urban tree root systems and their survival near houses analyzed using ground penetrating radar and sap flow techniques, Plant Soil, 219, 103-116, 2000.

Cheng, N.-F., Tang, H.-W. C., and Ding, X.-L.: A 3D model on tree root system using ground penetrating radar, Sustain. Environ. Res., 24, 291-301, 2014

Chrétien, M., Lataste, J. F., Fabre, R., and Denis, A.: Electrical resistivity tomography to understand clay behavior during seasonal water content variations, Eng. Geol., 169, 112-123, https://doi.org/10.1016/j.enggeo.2013.11.019, 2014.
Cosentini, R. M., Della Vecchia, G., Foti, S., and Musso, G.: Estimation of the hydraulic parameters of unsaturated samples by electrical resistivity tomography, Geotechnique, 62, 583-594, https://doi.org/10.1680/geot.10.P.066, 2012.

Cox, K. D., Scherm, H., and Serman, N.: Ground-penetrating radar to detect and quantify residual root fragments following peach orchard clearing, Horttechnology, 15, 600-607, 2005.

Cui, X. H., Chen, J., Shen, J. S., Cao, X., Chen, X. H., and Zhu, X. L.: Modeling tree root diameter and biomass by ground-penetrating radar, Sci. China Earth Sci., 54, 711-719, https://doi.org/10.1007/s11430-010-4103-z, 2011.

Dahboosh Al-Shiejiri, S. J.: Investigation of Subsidence Phenomena by GPR Technique and Geotechnical Evaluation in Baghdad City, MSc, College of Science, Department of Geology, University of Baghdad, Baghdad, Iraq, 117 pp., 2013.

Daniels, D. J.: Surface-penetrating radar, Electron. Commun. Eng., 8, 165-182, https://doi.org/10.1049/ecej:19960402, 1996.

Dannoura, M., Hirano, Y., Igarashi, T., Ishii, M., Aono, K., Yamase, K., and Kanazawa, Y.: Detection of Cryptomeria japonica roots with ground penetrating radar, Plant Biosyst., 142, 375380, https://doi.org/10.1080/11263500802150951, 2008.

da Silva, C. C. N., de Medeiros, W. E., de Sa, E. F. J., and Neto, P. X.: Resistivity and ground-penetrating radar images of fractures in a crystalline aquifer: a case study in Caicara farm - NE Brazil, J. Appl. Geophys., 56, 295-307, https://doi.org/10.1016/j.jappgeo.2004.08.001, 2004.

Doolittle, J. and Butnor, J.: Soils, peatlands and biomonitoring, in: Ground penetrating radar: theory and applications, edited by: Jol, H., Elsevier, Amsterdam, the Netherlands, 177-192, 2009.

Estrada-Medina, H., Tuttle, W., Graham, R. C., Allen, M. F., and Jimenez-Osornio, J. J.: Identification of Underground Karst Features using Ground-Penetrating Radar in Northern Yucatan, Mexico, Vadose Zone J., 9, 653-661, https://doi.org/10.2136/vzj2009.0116, 2010.

Estrada-Medina, H., Graham, R., Allen, M., Jiménez-Osornio, J., and Robles-Casolco, S.: The importance of limestone bedrock and dissolution karst features on tree root distribution in northern Yucatán, México, Plant Soil, 362, 37-50, https://doi.org/10.1007/s11104-012-1175-x, 2013.

FAO: World reference base for soil resources, IUSS, ISRIC, FAO, Rome, Italy, 128 pp., 2006.

Fernandez, M., Gil, L., and Pardos, J. A.: Effects of water supply on gas exchange in Pinus pinaster Ait. provenances during their first growing season, Ann. Forest Sci., 57, 9-16, 2000.

Guo, L., Chen, J., Cui, X. H., Fan, B. H., and Lin, H.: Application of ground penetrating radar for coarse root detection and quantification: a review, Plant Soil, 362, 1-23, https://doi.org/10.1007/s11104-012-1455-5, 2013.

Heggy, E., Paillou, P., Costard, F., Mangold, N., Ruffie, G., Demontoux, F., Grandjean, G., and Malezieux, J. M.: Local geoelectrical models of the Martian subsurface for shallow groundwater detection using sounding radars, J. Geophys. Res.-Planet., 108, 8030, https://doi.org/10.1029/2002je001871, 2003.

Hirano, Y., Dannoura, M., Aono, K., Igarashi, T., Ishii, M., Yamase, K., Makita, N., and Kanazawa, Y.: Limiting factors in the detection of tree roots using ground-penetrating radar, Plant Soil, 319, 15-24, https://doi.org/10.1007/s11104-008-9845-4, 2009.

Hirano, Y., Yamamoto, R., Dannoura, M., Aono, K., Igarashi, T., Ishii, M., Yamase, K., Makita, N., and Kanazawa, Y.: Detec- 
tion frequency of Pinus thunbergii roots by ground-penetrating radar is related to root biomass, Plant Soil, 360, 363-373, https://doi.org/10.1007/s11104-012-1252-1, 2012.

Hruska, J., Cermak, J., and Sustek, S.: Mapping tree root systems with ground-penetrating radar, Tree Physiol., 19, 125-130, 1999.

Hultine, K. R., Cable, W. L., Burgess, S. S. O., and Williams, D. G.: Hydraulic redistribution by deep roots of a Chihuahuan Desert phreatophyte, Tree Physiol., 23, 353-360, 2003.

Jackson, R. B., Canadell, J., Ehleringer, J. R., Mooney, H. A., Sala, O. E., and Schulze, E. D.: A global analysis of root distributions for terrestrial biomes, Oecologia, 108, 389-411, https://doi.org/10.1007/BF00333714, 1996.

Jackson, R. B., Sperry, J. S., and Dawson, T. E.: Root water uptake and transport: using physiological processes in global predictions, Trends Plant Sci., 5, 482-488, https://doi.org/10.1016/s1360-1385(00)01766-0, 2000.

Jayawickreme, D. H., Jobbagy, E. G., and Jackson, R. B.: Geophysical subsurface imaging for ecological applications, New Phytol., 201, 1170-1175, https://doi.org/10.1111/nph.12619, 2014.

Katra, I., Lavee, H., and Sarah, P.: The effect of rock fragment size and position on topsoil moisture on arid and semi-arid hillslopes, Catena, 72, 49-55, https://doi.org/10.1016/j.catena.2007.04.001, 2008.

König, F., Knödel, K., Mittenzwey, K.-H., and Weidelt, P.: Geophysical In-situ Groundwater and Soil Monitoring, in: Environ. Geol., Springer Berlin Heidelberg, Germany, 475-505, 2007.

Krivoruchko, K.: Empirical Bayesian Kriging, implemented in ArcGIS Geostatistical analist, available at: http://www.esri.com/ news/arcuser/1012/files/ebk.pdf (last access: 26 August 2016), 2012.

Kutschera, L. and Lichtenegger, E.: Wurzelatlas mitteleuropäischer Waldbäume und Sträucher, Stocker, Wien, Austria, 2002.

Lebourgeois, F., Levy, G., Aussenac, G., Clerc, B., and Willm, F.: Influence of soil drying on leaf water potential, photosynthesis, stomatal conductance and growth in two black pine varieties, Ann. Sci. Forest, 55, 287-299, 1998.

Li, S. G., Romero-Saltos, H., Tsujimura, M., Sugimoto, A., Sasaki, L., Davaa, G., and Oyunbaatar, D.: Plant water sources in the cold semiarid ecosystem of the upper Kherlen River catchment in Mongolia: A stable isotope approach, J. Hydrol., 333, 109117, https://doi.org/10.1016/j.jhydrol.2006.07.020, 2007.

Loke, M. H.: Tutorial: 2-D and 3-D electrical imaging surveys, available at: https://sites.ualberta.ca/ unsworth/UA-classes/223/ loke_course_notes.pdf (last access: 23 August 2016), 2004.

Martinez-Pagan, P., Gomez-Ortiz, D., Martin-Crespo, T., Manteca, J. I., and Rosique, M.: The electrical resistivity tomography method in the detection of shallow mining cavities. A case study on the Victoria Cave, Cartagena (SE Spain), Eng. Geol., 156, 110, https://doi.org/10.1016/j.enggeo.2013.01.013, 2013.

McDowell, F. W. and Keizer, R. P.: Timing of midTertiary volcanism in the Sierra Madre Occidental between Durango City and Mazatlan, Mexico, Geol. Soc. Am. Bull., 88, 1479-1487, https://doi.org/10.1130/00167606(1977)88<1479:tomvit>2.0.co;2, 1977.

Nijland, W., van der Meijde, M., Addink, E. A., and de Jong, S. M.: Detection of soil moisture and vegetation water abstraction in a Mediterranean natural area using electrical resistivity tomography, Catena, 81, 209-216, https://doi.org/10.1016/j.catena.2010.03.005, 2010.
Ogretmen, Z. and Seren, A.: Investigating fracture-cracked systems with geophysical methods in Bayburt Kiratli travertine, J. Geophys. Eng., 11, 065009, https://doi.org/10.1088/17422132/11/6/065009, 2014.

Orellana, E. and Silva, E. O.: Prospección geoeléctrica en corriente continua, parte 1, Paraninfo, Madrid, Spain, 578 pp., 1982.

Ow, L. F. and Sim, E. K.: Detection of urban tree roots with the ground penetrating radar, Plant Biosyst., 146, 288-297, https://doi.org/10.1080/11263504.2012.731018, 2012.

Parsekian, A. D., Singha, K., Minsley, B. J., Holbrook, W. S., and Slater, L.: Multiscale geophysical imaging of the critical zone, Rev. Geophys., 53, 1-26, https://doi.org/10.1002/2014rg000465, 2015.

Perez, S. M., Arredondo, M. J. T., Huber, S. E., and Vargas, H. J. J.: Production and quality of senesced and green litterfall in a pineoak forest in central-northwest Mexico, Forest Ecol. Manag., 258, 1307-1315, https://doi.org/10.1016/j.foreco.2009.06.031, 2009.

Poot, P. and Lambers, H.: Shallow-soil endemics: adaptive advantages and constraints of a specialized root-system morphology, New Phytol., 178, 371-381, https://doi.org/10.1111/j.14698137.2007.02370.x, 2008.

Poulos, H. M., Goodale, U. M., and Berlyn, G. P.: Drought response of two Mexican oak species, Quercus laceyi and Q-sideroxyla (Fagaceae), in relation to elevational position, Am. J. Bot., 94, 809-818, https://doi.org/10.3732/ajb.94.5.809, 2007.

Prieto, I., Armas, C., and Pugnaire, F. I.: Hydraulic lift promotes selective root foraging in nutrient-rich soil patches, Funct. Plant Biol., 39, 804-812, https://doi.org/10.1071/FP12070, 2012.

Proust, D., Caillaud, J., Fontaine, C., Fialin, M., Courbe, C., and Dauger, N.: Fissure and mineral weathering impacts on heavy metal distribution in sludge-amended soil, Plant Soil, 346, 2944, https://doi.org/10.1007/s11104-011-0791-1, 2011.

Querejeta, J., Estrada-Medina, H., Allen, M., and Jiménez-Osornio, J.: Water source partitioning among trees growing on shallow karst soils in a seasonally dry tropical climate, Oecologia, 152, 26-36, 2007.

Raz-Yaseef, N., Koteen, L., and Baldocchi, D. D.: Coarse root distribution of a semi-arid oak savanna estimated with ground penetrating radar, J. Geophys. Res.-Biogeo., 118, 135-147, https://doi.org/10.1029/2012jg002160, 2013.

Renee, B. J., Barnard, H. R., Coulombe, R., and McDonnell, J. J.: Ecohydrologic separation of water between trees and streams in a Mediterranean climate, Nat. Geosci., 3, 100-104, https://doi.org/10.1038/ngeo722, 2010.

Rodriguez-Robles, U., Arredondo, J. T., Huber-Sannwald, E., and Vargas, R.: Geoecohydrological mechanisms couple soil and leaf water dynamics and facilitate species coexistence in shallow soils of a tropical semiarid mixed forest, New Phytol., 207, 59-69, https://doi.org/10.1111/nph.13344, 2015.

Rose, K. L., Graham, R. C., and Parker, D. R.: Water source utilization by Pinus jeffreyi and Arctostaphylos patula on thin soils over bedrock, Oecologia, 134, 46-54, https://doi.org/10.1007/s00442002-1084-4, 2003.

Samouëlian, A., Cousin, I., Tabbagh, A., Bruand, A., and Richard, G.: Electrical resistivity survey in soil science: a review, Soil Till. Res., 83, 173-193, https://doi.org/10.1016/j.still.2004.10.004, 2005. 
Schwinning, S.: The water relations of two evergreen tree species in a karst savanna, Oecologia, 158, 373-383, https://doi.org/10.1007/s00442-008-1147-2, 2008.

Schwinning, S.: The ecohydrology of roots in rocks, Ecohydrology, 3, 238-245, https://doi.org/10.1002/eco.134, 2010.

Schwinning, S.: Do we need new rhizosphere models for rock-dominated landscapes?, Plant Soil, 362, 25-31, https://doi.org/10.1007/s11104-012-1482-2, 2013.

Schwinning, S. and Ehleringer, J. R.: Water use trade-offs and optimal adaptations to pulse-driven arid ecosystems, J. Ecol., 89, 464-480, https://doi.org/10.1046/j.1365-2745.2001.00576.x, 2001.

Srayeddin, I. and Doussan, C.: Estimation of the spatial variability of root water uptake of maize and sorghum at the field scale by electrical resistivity tomography, Plant Soil, 319, 185-207, https://doi.org/10.1007/s11104-008-9860-5, 2009.

Sudha, K., Israil, M., Mittal, S., and Rai, J.: Soil characterization using electrical resistivity tomography and geotechnical investigations, J. Appl. Geophys., 67, 74-79, https://doi.org/10.1016/j.jappgeo.2008.09.012, 2009.

Tanikawa, T., Hirano, Y., Dannoura, M., Yamase, K., Aono, K., Ishii, M., Igarashi, T., Ikeno, H., and Kanazawa, Y.: Root orientation can affect detection accuracy of ground-penetrating radar, Plant Soil, 373, 317-327, https://doi.org/10.1007/s11104-0131798-6, 2013.

Tokumoto, I., Heilman, J. L., Schwinning, S., McInnes, K. J., Litvak, M. E., Morgan, C. L. S., and Kamps, R. H.: Small-scale variability in water storage and plant available water in shallow, rocky soils, Plant Soil, 385, 193-204, https://doi.org/10.1007/s11104-014-2224-4, 2014.
Travelletti, J., Sailhac, P., Malet, J. P., Grandjean, G., and Ponton, J.: Hydrological response of weathered clay-shale slopes: water infiltration monitoring with time-lapse electrical resistivity tomography, Hydrol. Process., 26, 2106-2119, https://doi.org/10.1002/hyp.7983, 2012.

Van Dam, R. L.: Calibration Functions for Estimating Soil Moisture from GPR Dielectric Constant Measurements, Commun. Soil Sci. Plan., 45, 392-413, https://doi.org/10.1080/00103624.2013.854805, 2014.

Wang, T., Stodt, J. A., Stierman, D. J., and Murdoch, L. C.: Borehole Geophysics Mapping hydraulic fractures using a boreholeto-surface electrical resistivity method, Geoexploration, 28, 349369, https://doi.org/10.1016/0016-7142(91)90041-A, 1991.

Yan, H., Dong, X., Feng, G., Zhang, S., and Mucciardi, A.: Coarse root spatial distribution determined using a groundpenetrating radar technique in a subtropical evergreen broadleaved forest, China, Sci. China Life Sci., 56, 1038-1046, https://doi.org/10.1007/s11427-013-4560-7, 2013.

Zenone, T., Morelli, G., Teobaldelli, M., Fischanger, F., Matteucci, M., Sordini, M., Armani, A., Ferre, C., Chiti, T., and Seufert, G.: Preliminary use of ground-penetrating radar and electrical resistivity tomography to study tree roots in pine forests and poplar plantations, Funct. Plant Biol., 35, 1047-1058, https://doi.org/10.1071/fp08062, 2008.

Zhu, S., Huang, C., Su, Y., and Sato, M.: 3D Ground Penetrating Radar to Detect Tree Roots and Estimate Root Biomass in the Field, Remote Sens., 6, 5754-5773, https://doi.org/10.3390/rs6065754, 2014. 